\title{
CHANCELLOR GRAHAM ROUTLEDGE
}

The death of Graham Routledge at the early age of 61 came as no surprise to those who had anxiously watched his courageous struggle against an unrelenting illness. He will be sadly missed in legal, clerical and academic circles, and especially by the members of the Ecclesiastical Law Society which owes so much to his energy and foresight. His was a full life. From school he went straight to do his National Service in the Army. When he was released, he entered the University of Liverpool, where he took a first class honours degree in Law, to be followed by a scholarship at the Middle Temple. He then practised at the Bar as a junior in Liverpool, largely on the Chancery side, and he also unsuccessfully contested a Parliamentary election in Birkenhead for the Conservatives. Suddenly he threw up his practice in order to go to Fitzwilliam College and Westcott House, Cambridge, to prepare for ordination. There followed a short period as an assistant curate at St. George's, Stockport, together with a lectureship in law at Manchester. Before long he was offered and accepted a Fellowship at Corpus Christi College, Cambridge, together with the offices of Dean of Chapel and Director of Studies in Law. In a brief space of time he was appointed Chancellor of Ely, of Peterborough and of Lichfield, and he left Cambridge to become, first, Canon and Treasurer of Peterborough Cathedral, and then Canon and Treasurer of St. Paul's Cathedral. In the latter post he probably provided a healthy corrective to some rather radical tendencies which were beginning to be manifested, for he was by nature both conservative and orthodox, though by no means hide-bound. While he may not have been a profound lawyer, in all things he was thorough and energetic. Before his time attempts had been made with some success to promote and increase the study of Canon Law and Ecclesiastical Law. Routledge was quick to appreciate the importance of this and to see the necessity of bringing together clerics, lawyers and historians, and it is largely due to his energy that the Ecclesiastical Law Society was so successfully launched. He leaves behind his widow, Muriel, to whose cooperation he undoubtedly owed so much.

E.G.M. 